\title{
DIMENSIONS OF JERUSALEM-ARTICHOKE COSSETTES
}

\author{
By Max J. Proffict, John A. Bogan, and Richard F. Jackson
}

\section{ABSTRACT}

Cossettes were prepared from jerusalem-artichoke tubers in an experimental slicer equipped with a commercial beet knife set $1.5 \mathrm{~mm}$ up and $4.5 \mathrm{~mm}$ back. The tubers were of a size at least as large as the present average, yet the mean length of all particles was $1.163 \mathrm{~cm}$, which is less than $0.5 \mathrm{in}$. The class composed of fragments less than $1 \mathrm{~cm}$ in length comprised nearly 60 percent of the total number of particles, occupied more than 20 percent of the total displacement volume, and presented nearly 25 percent of the gross surface area. The class under $4 \mathrm{~cm}$ in length comprised 96 percent of the total number, occupied 81 percent of the total displacement volume, and presented 83 percent of the gross surface area. This indicates high resistance to the flow of flood liquid in batteries of commercial size. The gross external area of all particles was slightly in excess of $2 \mathrm{~m}^{2} / \mathrm{dm}^{3}$ of displacement volume, and equivalent to approximately $62.8 \mathrm{ft}^{2} / \mathrm{ft}^{3}$. The mean thickness of the diffusion layers, estimated from the ideal and observed mean cross-sectional profiles of the cossettes and the results of wetting experiments, apparently was about $0.086 \mathrm{~cm}$ for the condition of complete establishment of diffusion gradients. These values are of importance in estimating the coefficient of diffusion for the polysaccharides of the tubers under the conditions of battery extraction, to be presented in a later paper.

\section{CONTENTS}

I. Introduction

II. Summary of dimensions

III. Apparatus _... 617

IV. Experimental Details

1. Lengths of cossettes 617

2. Cross-sectional profiles

3. Total lengths and frequencies

4. External surface areas _. 619

5. Volumes of classes

6. Ideal density of packing 619

7. Size of tubers

8. Thickness of diffusion layers

9. Reliability of estimates._. 624

\section{INTRODUCTION}

The measurements reported in the present paper were made (1) for the purpose of appraising and indicating the physical quality to be expected of cossettes prepared from jerusalem-artichoke tubers, and (2) to obtain data for the estimation of the coefficient of diffusion of the polysaccharides of the tubers under the conditions of battery extraction. Each is a very important consideration in the design of equipment for the production of levulose from this source. 


\section{SUMMARY OF DIMENSIONS}

Owing to their small size and knobby shape in the present state of development, jerusalem-artichoke tubers yield cossettes which are predominantly short. To appreciate quantitatively the shortness of experimental cossettes prepared from tubers of at least average size, the lengths of the slices are subjected to statistical analysis. The measured lengths of all the particles in a sample are grouped into classes differing successively by increments of $1 \mathrm{~cm}$. Arbitrarily, particles less than $1 \mathrm{~cm}$ in length are considered "fragments"; those longer than $1 \mathrm{~cm}$ true cossettes. The relative magnitude of a class is stated as a percentage of the whole sample with respect to (a) the frequency or number of particles; (b) the displacement volume of the tuber substance; and (c) the external surface area of the component particles.

For example, the mean results (table 2) indicate that the fragments, of which the maximum length was $1 \mathrm{~cm}$, roughly $3 / 8$ in., accounted for more than 50 percent of the frequency, for nearly 25 percent of the external area, and for more than 20 percent of the displacement volume of the whole sample. The group between zero and $4 \mathrm{~cm}$ (1.57 in.) in length contained 96 percent of the total number of particles; 81 percent of the aggregate displacement volume; and 83 percent of the total external area of all particles. The cumulative relative magnitudes within this group, as separately estimated by two observers, are presented in table 1.

\section{TABLE 1.-Distribution of the classes under $4 \mathrm{~cm}$ in length}

\begin{tabular}{|c|c|c|c|}
\hline \multirow[b]{2}{*}{ Class length less than-- } & \multicolumn{3}{|c|}{ Magnitude of class, basis of- } \\
\hline & Frequency & $\begin{array}{c}\text { Displace- } \\
\text { ment } \\
\text { volume }\end{array}$ & $\begin{array}{c}\text { External } \\
\text { area }\end{array}$ \\
\hline $\begin{array}{c}c m \\
12 \\
2 \\
4\end{array}$ & $\begin{array}{l}\text { Percent } \\
53 \text { and } 65 \\
79 \text { and } 82 \\
90 \text { and } 91 \\
95 \text { and } 96\end{array}$ & $\begin{array}{c}\text { Percent } \\
19 \text { and } 24 \\
45 \text { and } 46 \\
63 \text { and } 68 \\
79 \text { and } 83\end{array}$ & $\begin{array}{l}\text { Percent } \\
22 \text { and } 27 \\
48 \text { and } 49 \\
65 \text { and } 70 \\
81 \text { and } 84\end{array}$ \\
\hline
\end{tabular}

The data presented above indicate that artichoke cossettes prepared with ordinary beet slicers and treated in the conventional diffusion apparatus of commercial capacity probably would offer excessive resistance to the flow of the flood liquid. For this reason the projected large-scale extraction of the polysaccharides from jerusalem artichokes may require a form of apparatus and a shape of slices which are decidedly different from those employed at present in the extraction of sucrose from beets. Since a different shape of slices may involve important differences in the effective surface area and mean thickness of the diffusion layers, considerable effort has been devoted to the estimation of these factors in material such as that actually employed in the experimental extractions of the polysaccharides. These estimates are based mainly upon the same measurements as those from which the length distributions were appraised.

The measurements indicate that with the knife-setting stated below the mean surface area of the cossettes was approximately $2.06 \mathrm{~m}^{2} / \mathrm{dm}^{3}$ 
of displacement volume, and that the mean thickness of each limb of the cross-sectional profile of a cossette, assuming a symmetrical figure, was approximately $0.138 \mathrm{~cm}$. Experiments with wetting the cossettes with flood liquid and draining indicate that the adherent film may have been approximately $0.017 \mathrm{~cm}$ in thickness, suggesting that after the diffusion gradients were fully established the mean thickness of diffusion layers may have been approximately $0.086 \mathrm{~cm}$. These are the values assumed for the mean external area and the mean thickness of the diffusion layers, respectively, in the estimation of coefficients to be presented in a later paper.

\section{APPARATUS}

The slicer employed in the preparation of the cossettes has been described very briefly, ${ }^{1}$ and its construction is illustrated in figure 1. In operation, washed tubers are placed in the hopper and forced into contact with the reciprocating beet knife by means of the handoperated plunger, seen best in the plan view. The knife, $137 \mathrm{~mm}$ in width and having 30 divisions, was set $1.5 \mathrm{~mm}$ up and $4.5 \mathrm{~mm}$ back. With this setting and at a speed of 131 cutting strokes a minute the slicer had a capacity of about $3.7 \mathrm{~kg} / \mathrm{min}$, equivalent to $28 \mathrm{~g}$ at a stroke.

\section{EXPERIMENTAL DETAILS}

\section{LENGTHS OF COSSETTES}

From a single batch of cossettes prepared in the manner described, two samples were taken at random and weighed. Observers $B$ and $C$ each measured and recorded the length of every particle of tuber substance in one of these samples. Each piece was grasped individually with the forceps and placed on a millimeter scale. The weights of the samples and the number and mean length of particles in each class of each sample are presented in table 2 .

TABLE 2.-Distribution of particies by length

OBSERVER B, 36.5-GRAM SAMPLE

\begin{tabular}{|c|c|c|c|c|c|c|c|c|c|c|c|}
\hline \multirow{2}{*}{$\begin{array}{l}\text { Class } \\
\text { range }\end{array}$} & \multicolumn{3}{|c|}{$\begin{array}{l}\text { Particle distribution as } \\
\text { observed in sample }\end{array}$} & \multicolumn{3}{|c|}{$\begin{array}{l}\text { Particle distribution per } \\
\mathrm{dm}^{3} \text { (equivalent in } \\
1.040 \mathrm{~kg} \text { ) }\end{array}$} & \multicolumn{4}{|c|}{$\begin{array}{c}\text { Relative magnitude of class, } \\
\text { basis of }\end{array}$} & \multirow{2}{*}{$\begin{array}{l}\text { Length, } \\
\text { percent } \\
\times \text { mean } \\
\text { length }\end{array}$} \\
\hline & $\begin{array}{l}\text { Mean } \\
\text { length }\end{array}$ & $\begin{array}{l}\text { Fre- } \\
\text { quency }\end{array}$ & $\begin{array}{l}\text { Total } \\
\text { length }\end{array}$ & $\begin{array}{l}\text { Fre- } \\
\text { quency }\end{array}$ & $\begin{array}{l}\text { Total } \\
\text { class } \\
\text { length }\end{array}$ & $\begin{array}{l}\text { Exter- } \\
\text { nal area } \\
\text { of class }\end{array}$ & $\begin{array}{c}\text { Fre- } \\
\text { quency }\end{array}$ & $\begin{array}{l}\text { Exter- } \\
\text { nal } \\
\text { area }\end{array}$ & $\begin{array}{l}\text { Length } \\
\text { or vol- } \\
\text { ume }\end{array}$ & $\begin{array}{l}\text { Inverse } \\
\text { cumu- } \\
\text { lative } \\
\text { volume }\end{array}$ & \\
\hline $\begin{array}{c}\mathrm{mm} \\
0-9 \\
10-19 \\
20-29 \\
30-39\end{array}$ & $\begin{array}{c}\mathrm{mm} \\
3.94 \\
13.95 \\
23.38 \\
31.93\end{array}$ & $\begin{array}{r}232 \\
59 \\
29 \\
20\end{array}$ & $\begin{array}{c}\mathrm{mm} \\
915 \\
823 \\
678 \\
639\end{array}$ & $\begin{array}{r}6,610 \\
1,681 \\
826 \\
570\end{array}$ & $\begin{array}{l}\mathrm{cm} \\
2,608 \\
2,345 \\
1,932 \\
1,821\end{array}$ & $\begin{array}{l}\mathrm{cm}^{3} \\
5,617 \\
4,273 \\
3,418 \\
3,184\end{array}$ & $\begin{array}{r}\text { Percent } \\
65.2 \\
16.6 \\
8.2 \\
5.6\end{array}$ & \begin{tabular}{|r|} 
Percent \\
27.6 \\
20.9 \\
16.8 \\
15.6
\end{tabular} & $\begin{array}{c}\text { Percent } \\
23.8 \\
21.4 \\
17.6 \\
16.6\end{array}$ & $\begin{array}{r}\text { Percent } \\
100.0 \\
76.2 \\
54.8 \\
37.2\end{array}$ & $\begin{array}{r}94 \\
299 \\
412 \\
530\end{array}$ \\
\hline $\begin{array}{l}40-49 \\
50-59 \\
60-69 \\
70-79\end{array}$ & $\begin{array}{l}43.11 \\
56.00 \\
63.00\end{array}$ & $\begin{array}{l}9 \\
4 \\
3 \\
0\end{array}$ & $\begin{array}{r}388 \\
214 \\
189 \\
\end{array}$ & $\begin{array}{r}257 \\
114 \\
86 \\
0\end{array}$ & $\begin{array}{r}1,106 \\
610 \\
538 \\
\end{array}$ & $\begin{array}{r}1,917 \\
1,053 \\
926\end{array}$ & $\begin{array}{r}2.5 \\
1.1 \\
.8 \\
.0\end{array}$ & $\begin{array}{r}9.4 \\
5.2 \\
4.5 \\
-\end{array}$ & $\begin{array}{r}10.1 \\
5.6 \\
4.9 \\
\end{array}$ & $\begin{array}{r}20.6 \\
10.5 \\
4.9 \\
\end{array}$ & $\begin{array}{r}435 \\
311 \\
309 \\
\end{array}$ \\
\hline $0-79$ & 10.80 & 356 & 3,846 & 10,144 & 10,959 & 20,388 & 100.0 & 100.0 & 100.0 & & 1,080 \\
\hline
\end{tabular}

1 M. J. Proffitt, J. Research NBS 15, 459 (1935) RP840; Ind. Eng. Chem. 27, 1273 (1935). 
TABLE 2.-Distribution of particles by length-Continued

\section{FRAGMENTS}

\begin{tabular}{|c|c|c|c|c|c|c|c|c|c|c|c|}
\hline \multirow{2}{*}{$\begin{array}{l}\text { Class } \\
\text { range }\end{array}$} & \multicolumn{3}{|c|}{$\begin{array}{l}\text { Particle distribution as } \\
\text { observed in sample }\end{array}$} & \multicolumn{3}{|c|}{$\begin{array}{l}\text { Particle distribution per } \\
\mathrm{dm}^{3} \text { (equivalent in } \\
1.040 \mathrm{~kg} \text { ) }\end{array}$} & \multicolumn{4}{|c|}{ Relative magnitude of class, } & \multirow{2}{*}{$\begin{array}{l}\text { Length, } \\
\text { percent } \\
\times \text { mean } \\
\text { length }\end{array}$} \\
\hline & $\begin{array}{l}\text { Mean } \\
\text { length }\end{array}$ & $\begin{array}{l}\text { Fre- } \\
\text { quency }\end{array}$ & $\begin{array}{l}\text { Total } \\
\text { length }\end{array}$ & $\begin{array}{l}\text { Fre- } \\
\text { quency }\end{array}$ & $\begin{array}{l}\text { Total } \\
\text { Class } \\
\text { length }\end{array}$ & $\begin{array}{l}\text { Exter- } \\
\text { nal area } \\
\text { of class }\end{array}$ & $\begin{array}{l}\text { Fre- } \\
\text { quency }\end{array}$ & $\begin{array}{l}\text { Exter- } \\
\text { nal } \\
\text { area }\end{array}$ & $\begin{array}{l}\text { Length } \\
\text { or vol- } \\
\text { ume }\end{array}$ & $\begin{array}{l}\text { Inverse } \\
\text { cumu- } \\
\text { lative } \\
\text { volume }\end{array}$ & \\
\hline $\begin{array}{c}\mathrm{mm} \\
0-9\end{array}$ & $\mathrm{~mm}_{3.94}$ & 232 & $\mathrm{~mm}_{915}$ & 6,610 & $\begin{array}{l}\mathrm{cm} \\
2,608\end{array}$ & $\begin{array}{l}\mathrm{cm}^{3} \\
5,617\end{array}$ & $\begin{array}{c}\text { Percent } \\
65.2\end{array}$ & $\begin{array}{c}\text { Percent } \\
27.6\end{array}$ & $\begin{array}{r}\text { Percent } \\
23.8\end{array}$ & Percent & 94 \\
\hline \multicolumn{12}{|c|}{ COSSETTES } \\
\hline $10-79$ & 23.63 & 124 & 2,931 & 3,534 & 8,351 & 14,771 & 34.8 & 72.4 & 76.2 & & 1,801 \\
\hline
\end{tabular}

OBSERVER $C, 45.0-$ GRAM SAMPLE

\begin{tabular}{|c|c|c|c|c|c|c|c|c|c|c|c|}
\hline $0-9$ & 4. 41 & 213 & 940 & 4,923 & 2,172 & 4,498 & 53.2 & 21.7 & 19.0 & 100.0 & 84 \\
\hline $10-19$ & 13. 26 & 102 & 1,353 & 2,357 & 3,127 & 5,649 & 25.5 & 27.2 & 27.3 & 81.0 & 363 \\
\hline & 22.57 & 47 & 1,061 & 1,086 & 2,452 & 4,296 & 11.8 & 20.7 & 21.4 & 53.7 & 484 \\
\hline $30-39$ & 35.67 & 21 & 749 & 485 & 1,731 & 2,984 & 5.2 & 14. 3 & 15.1 & 32.2 & 540 \\
\hline $40-49$ & 46. 07 & 14 & 645 & 324 & 1,491 & 2,554 & 3.5 & 12.3 & 13. 1 & 17.1 & 601 \\
\hline $50-59$ & 52.00 & 1 & 52 & 23 & 120 & 205 & .3 & 1. 0 & 1.1 & 4.1 & 55 \\
\hline 70-79 & 74.00 & 2 & 148 & 46 & 342 & 581 & .0 & 2.8 & 3.0 & $\begin{array}{l}0.0 \\
3.0\end{array}$ & 221 \\
\hline $0-79$ & 12. 37 & 400 & 4,948 & 9,244 & 11,435 & 20,767 & 100.0 & 100.0 & 100.0 & & 1,237 \\
\hline
\end{tabular}

FRAGMENTS

\begin{tabular}{|c|c|c|c|c|c|c|c|c|c|c|c|}
\hline $0-9$ & 4. 41 & 213 & 940 . & 4,293 & 2,172 & 4,498 & 53. 2 & 21.7 & 19.0 & -........ & 84 \\
\hline \multicolumn{12}{|c|}{ COSSETTES } \\
\hline $10-79$ & 21.43 & 187 & 4,008 & 4,321 & 9,263 & 16,269 & 46.8 & 78.3 & 81.0 & & 1,736 \\
\hline
\end{tabular}

OBSERVERS $B+C, 81.5$-GRAM SAMPLE

\begin{tabular}{r|r|r|r|r|r|r|r|r|r|r|r}
\hline $0-9$ & 4.17 & 445 & 1,855 & 5,679 & 2,367 & 4,993 & 58.9 & 24.3 & 21.1 & 100.0 & 88 \\
$10-19$ & 13.51 & 161 & 2,175 & 2,054 & 2,776 & 5,035 & 21.3 & 24.5 & 24.7 & 78.9 & 334 \\
$20-29$ & 22.88 & 76 & 1,739 & 970 & 2,219 & 3,905 & 10.0 & 19.0 & 19.8 & 54.2 & 453 \\
$30-39$ & 33.85 & 41 & 1,388 & 523 & 1,771 & 3,072 & 5.4 & 14.9 & 15.8 & 34.4 & 534 \\
& & & & & & & & & & \\
$40-49$ & 44.91 & 23 & 1,033 & 293 & 1,318 & 2,269 & 3.0 & 11.0 & 11.8 & 18.6 & 528 \\
$50-59$ & 53.20 & 5 & 266 & 64 & 339 & 581 & .7 & 2.8 & 3.0 & 6.8 & 161 \\
$60-69$ & 63.00 & 3 & 189 & 38 & 241 & 412 & .4 & 2.0 & 2.1 & 3.8 & 135 \\
$70-79$ & 74.00 & 2 & 148 & 26 & 189 & 323 & .3 & 1.5 & 1.7 & 1.7 & 124 \\
\hline $0-79$ & 11.63 & 756 & 8,793 & 9,647 & 11,220 & 20,590 & 100.0 & 100.0 & 100.0 & $-\ldots . .5$ \\
\hline
\end{tabular}

FRAGMENTS

\begin{tabular}{|c|c|c|c|c|c|c|c|c|c|c|c|}
\hline $0-9$ & 4. 17 & 445 & 1,855 & 5,679 & 2,367 & 4,993 & 58.9 & 24.3 & 21.1 & $\ldots$ & 88 \\
\hline
\end{tabular}

COSSETTES

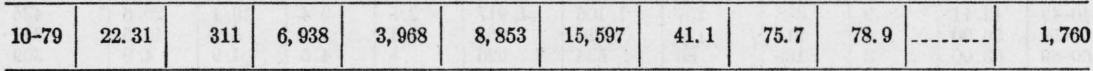




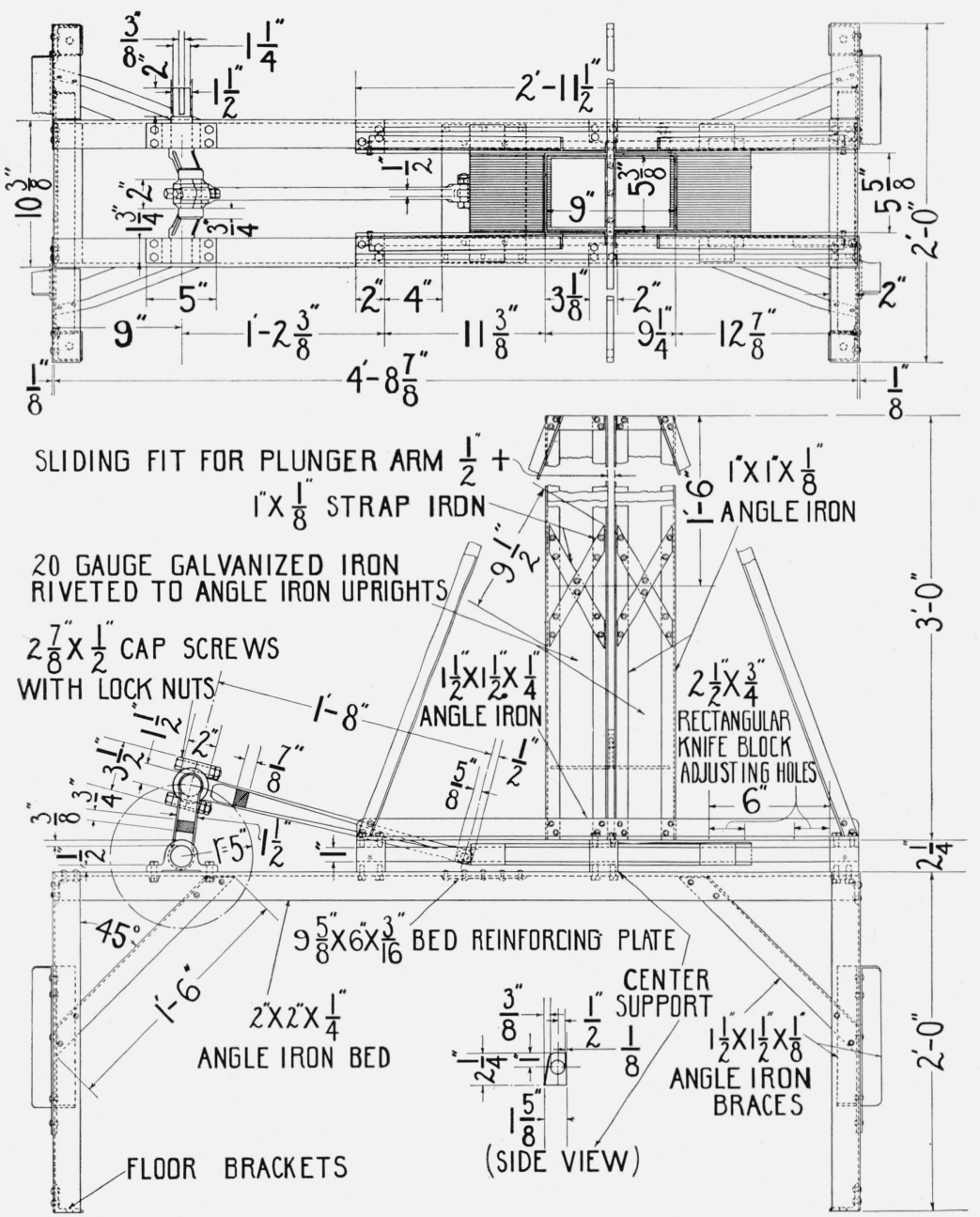

Figure 1.-Slicer.

Plan and side elevation. 


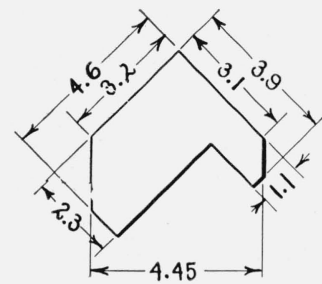

A

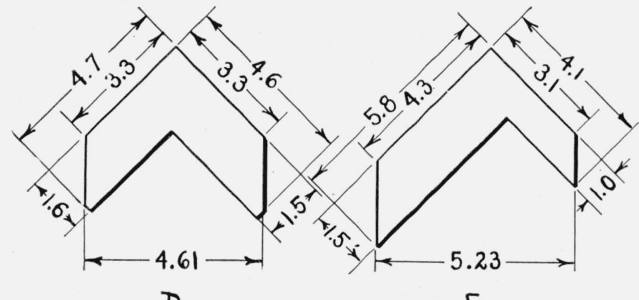

D

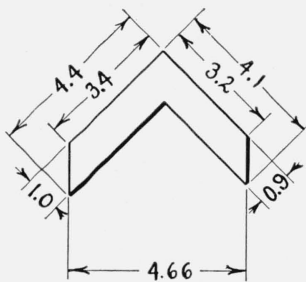

B

$E$

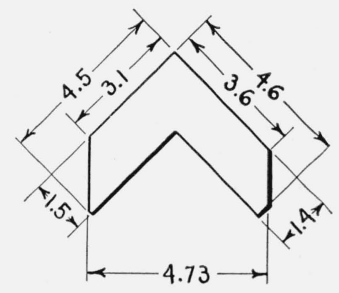

C

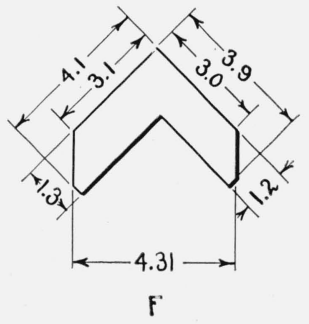

MEASURED CROSS-SECTIONS

DIMENSIONS IN MILLIMETERS

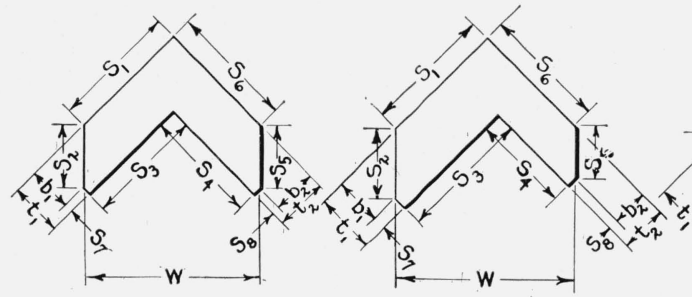

G SYMMETRICAL

MEAN FIGURES FROM MEASURED CROSS-SECTIONS

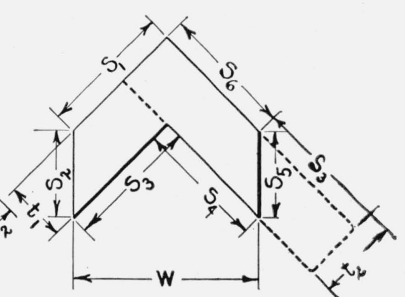

IDEAL

Figure 2.-Cross-sectional profiles of cossettes.

For dimensions of mean profiles see table 3. 


\section{CROSS-SECTIONAL PROFILES}

The dimensions of the cross-sectional profiles were estimated by two methods, as follows:

(a) Several sections from each of six cossettes, taken at random from the same batch of cossettes as the length samples, were cut on a microtome and measured by observer $A$ under a microscope with a calibrated ocular micrometer and a low-power objective. The mean values for each cossette are presented in sketches $A$ to $F$, figure 2 . All of the profiles are skew. The mean skew profile for the six cossettes is presented in sketch $H$, and the corresponding symmetrical profile in sketch $G$, figure 2 .

(b) It was assumed that the mean cross-sectional profile of the chips in the length-measurement samples of observers $B$ and $C$ was of the ideal form presented in sketch $I$, figure 2 , which is equivalent to the rectangle indicated by the broken outline, and that the width $w$ was $0.457 \mathrm{~cm}$ as indicated by the dimensions of the knife. The corresponding mean thickness $t$ was estimated from the total length of all the chips in the sample and the assumed density of $1.040 \mathrm{~g} / \mathrm{cm}^{3}$ as observed by $A$ in three whole tubers taken at random from the lot from which the cossettes were prepared. As indicated in table 3, the results for the two observers differ from their mean by \pm 2.2 percent, and their mean is identical with the thickness indicated for the mean symmetrical profile by method (a).

\section{TOTAL LENGTHS AND FREQUENCIES}

For observers $B$ and $C$ the total lengths and the frequencies in each class are taken directly from the recorded data. For observer $A$ the total length of chips is assumed to have been that indicated by the mean cross-sectional area; the total number (for estimating the total area of ends) is assumed to have been equal to the mean of the counts by observers $B$ and $C$ (table 3 ).

\section{EXTERNAL SURFACE AREAS}

The areas of the external surfaces are estimated on the basis of the respective mean perimeters and the number of ends, supposed to have been two ends to a particle, each end equal in area to the calculated area of the mean cross-sectional profile. No correction is made for either roughness of surface or thickness of adhering film during diffusion. (See tables 2 and 3.)

\section{VOLUMES OF CLASSES}

The volume occupied by a class is assumed to have been proportional to the aggregate length of its particles; hence the percentage magnitude of a class by volume is also its percentage magnitude by total length (table 2).

\section{IDEAL DENSITY OF PACKING}

If cossettes of uniform and symmetrical profile could be packed into a battery cell in perfect criss-cross arrangement without distortion, 
as suggested by the diagram for ideal packing in figure 3 , the maximum density of filling would be attained when the vertical sides of each cossette were in contact with corresponding sides, or with the ends of adjacent cossettes, or else with the walls of the cell. In such a state of filling, the internal space of a cell would be occupied by a myriad of "prismatic elements" (fig. 3), each consisting partly of cossette substance and partly of space available for flood liquid. The part of the volumetric capacity of the cell which would be occupied by cossette substance would be indicated by the ratio of the cross-sectional area,

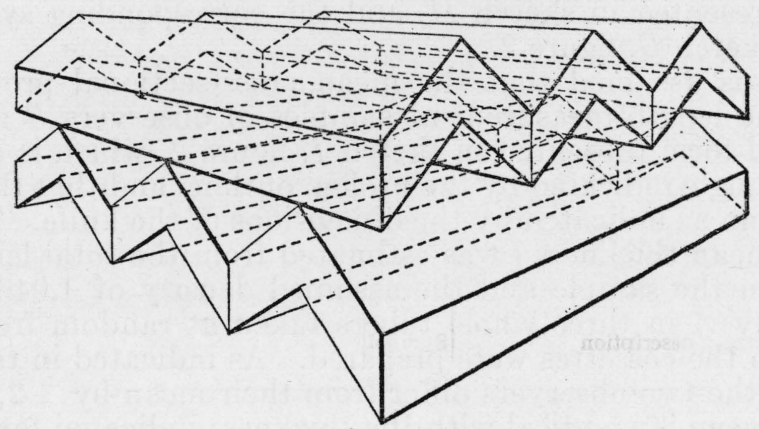

IDEAL CROSS-PACKING

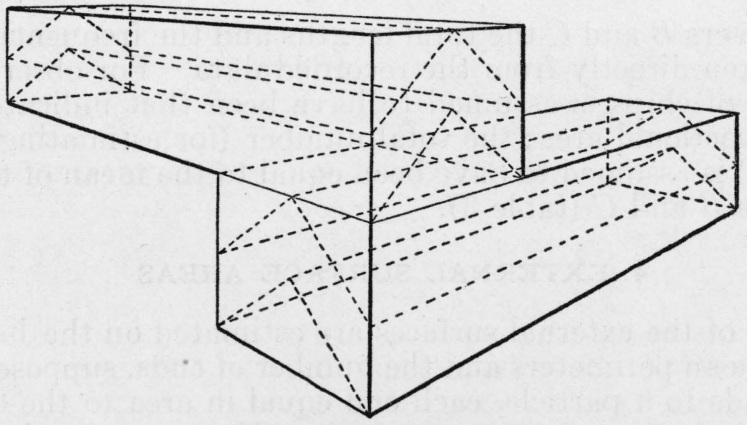

PRISMATIC ELEMENTS

FIGURE 3.-Arrangement of cossettes in ideal packing.

$a^{\prime}$, of the cossette profile to the cross-sectional area, $a$, of the prismatic element, and

$$
f^{\prime}=\frac{100 a^{\prime}}{a}
$$

would express the percentage of the whole capacity of the cell which would be devoted to the cossette substance. Since the space not occupied by cossette substance is available for flood liquid, inspection of the diagrams (figs. 2 and 3 ) indicates that the percentage of cell space available for flood liquid would be represented by the equation

$$
f^{\prime \prime}=\frac{100 s_{1}^{2}}{a}
$$


when the cossettes have the ideal profile; and since $s_{1}=s_{2}$ and $w=$ $2 s_{1} \sqrt{2}$, the relation is easily checked algebraically. The correction to be applied when the mean profile has clipped corners is obvious. Since the percentage filling of the cells is indicated by the relation

$$
f^{\prime}=100-f^{\prime \prime} \text {, }
$$

the calculated values for the hypothetical ideal filling of the cells, corresponding to the cross-sectional areas of the respective symmetrical profiles (ideal and mean), as presented in table 3 , vary from 46 to 48, while the observed values for random packing as attained in actual extraction experiments varied from 44 percent to 63 percent and averaged 52 percent of the cell space.

TABLE 3.-Estimated dimensions of jerusalem-artichoke cossettes

[Values for observer $A$ and method 1 refer to mean profiles $G$ or $H$; all others to ideal profile $I$, figure 2]

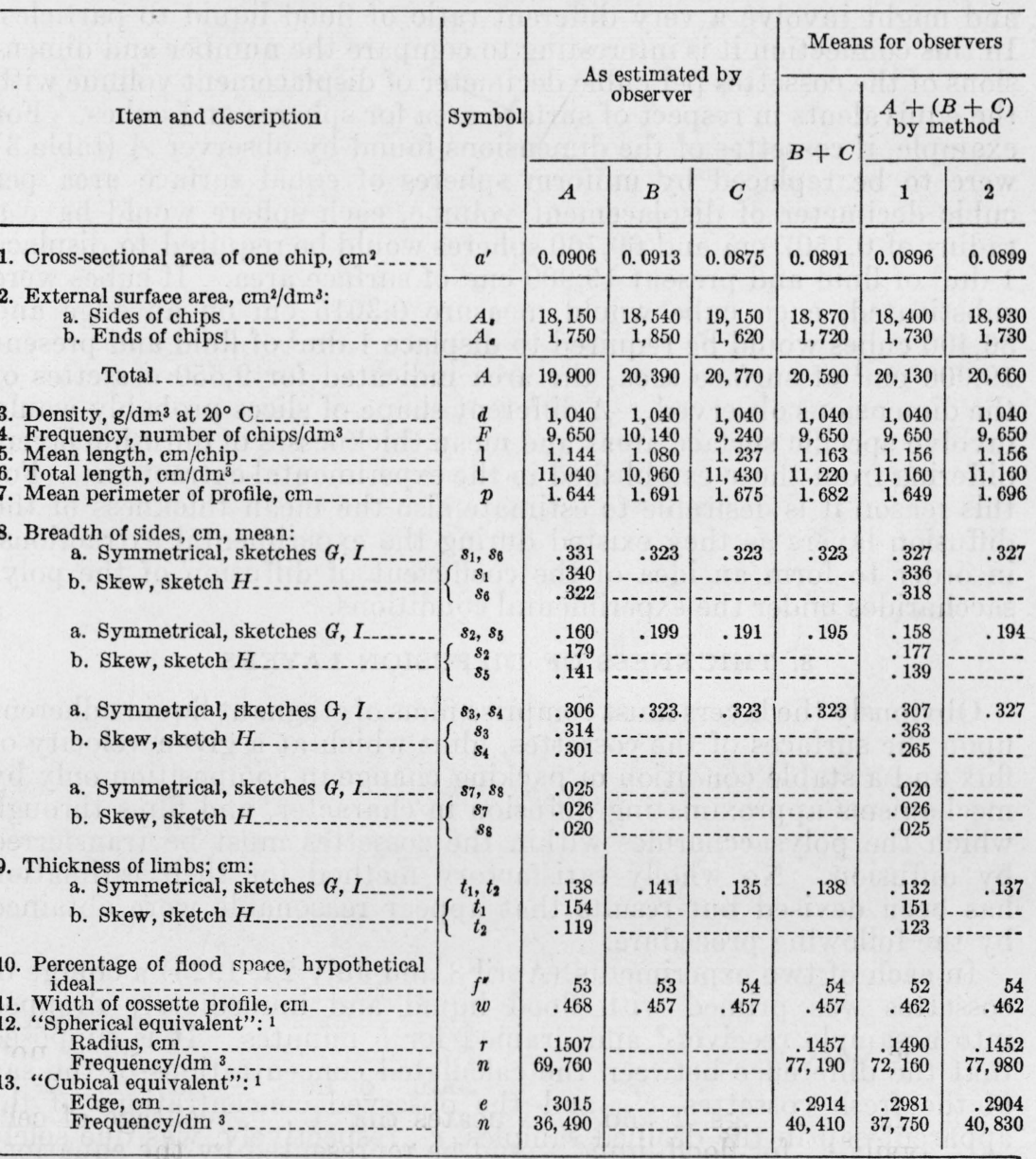

${ }^{1}$ Number and dimensions of spheres or cubes, respectively, having the same surface area, in $1 \mathrm{dm}^{3}$,as that estimated for the cossettes. 


\section{SIZE OF TUBERS}

The tubers from which the samples of cossettes were prepared averaged about $50 \mathrm{~g}$ in weight, which is rather larger than the average weight of jerusalem artichokes as they occur in the present state of development. Moreover, they probably were not more knobby than the general run of tubers; yet the mean length of slices according to both counts was less than half an inch. The length distribution of the particles according to either count (table 2) indicates that cossettes cut with the usual form of beet knife and handled in large masses, as would be necessary in the conventional form of commercial-scale diffusion apparatus, would present excessive resistance to the flow of the flood liquid. For this reason special equipment may have to be designed for the extraction of the polysaccharides from jerusalem artichokes. This may involve the slicing equipment as well as the extraction apparatus, when the process is converted to a commercial scale. The new design might accommodate a different shape of slices and might involve a very different ratio of flood liquid to particles. In this connection it is interesting to compare the number and dimensions of the cossettes per cubic decimeter of displacement volume with the equivalents in respect of surface area for spheres and cubes. For example, if cossettes of the dimensions found by observer $A$ (table 3 ) were to be replaced by uniform spheres of equal surface area per cubic decimeter of displacement volume, each sphere would have a radius of $0.1507 \mathrm{~cm}$ and 69,760 spheres would be required to displace $1 \mathrm{dm}^{3}$ of fluid and present $19,900 \mathrm{~cm}^{2}$ of surface area. If cubes were substituted, each cube would measure $0.3015 \mathrm{~cm}$ on an edge and 36,490 cubes would be required to displace $1 \mathrm{dm}^{3}$ of fluid and present $19,900 \mathrm{~cm}^{2}$ of surface area, the area indicated for 9,650 cossettes of the dimensions observed. A different shape of slices probably would involve specific surface areas and mean thicknesses of diffusion layers differing from those established in the experimental extractions. For this reason it is desirable to estimate also the mean thickness of the diffusion layers as they existed during the experimental extractions, in order to form an idea of the coefficient of diffusion of the polysaccharides under the experimental conditions.

\section{THICKNESS OF DIFFUSION LAYERS}

Obviously the layers must comprise films of stagnant liquid adherent upon the surfaces of the cossettes, films which at a given velocity of flux and a stable condition of packing change in composition only by mechanisms approximating diffusion in character, and films through which the polysaccharides within the cossettes must be transferred by diffusion. No wholly satisfactory method for their estimation has been devised but results that appear reasonable were obtained by the following procedure:

In each of two experiments (April 3 and July 23, 1925) a charge of cossettes was primed with flood liquid and immediately dropped into a sample receiver ${ }^{2}$ and drained for 5 minutes. It is supposed that the difference between the calculated concentrations of the sap of the fresh cossettes, $c^{\prime}{ }_{s}$, and the observed concentrations of the apparent sap in the drained samples, $c^{\prime}$, respectively, was due solely to the replacement of the free fresh sap (from ruptured tissues) on the surfaces of the cossettes with an equal volume of flood liquid of

\footnotetext{
${ }^{2}$ J. Research NBS 15, 458 (1935) RP840; Ind. Eng. Chem. 27, 1273 (1935).
} 
the concentration, $c^{\prime \prime}$, observed in the separated liquid. Thus, it is assumed that the volume of apparent sap in the drained sample was equal to the original volume of fresh sap in a charge of cossettes. Since this calculated total volume of fresh sap is $v^{\prime}$, the mixture (of concentration $c^{\prime}$ ) appearing as sap in the drained sample was composed of the volume, $v^{\prime \prime}{ }_{1}$, of flood liquid film that had replaced the free fresh sap and the volume, $v^{\prime}-v^{\prime \prime}{ }_{1}$, of actual fresh sap from inside the tissues. Granting this, it is evident that from the resulting relation

$$
\begin{gathered}
\left(v^{\prime}-v^{\prime \prime}{ }_{1}\right) c^{\prime}{ }_{s}+v^{\prime \prime}{ }_{1} c^{\prime \prime}=v^{\prime} c^{\prime}, \\
v^{\prime \prime}{ }_{1}=\frac{c_{s^{\prime}}-c^{\prime}}{c^{\prime}{ }_{s}-c^{\prime \prime}} v^{\prime} .
\end{gathered}
$$

The indicated thickness of the flood liquid film is then expressed by the equation

$$
L_{2}=\frac{v^{\prime \prime}}{A} 10^{-1},
$$

where $L_{2}$ stands for the thickness of the film in centimeters and $A$ represents the surface area of the cossettes expressed in square meters. The numerical data are presented in table 4. It is assumed that once diffusion gradients have become established throughout the tissues of the cossettes, the thickness of the diffusion layers is $L=L_{1}+$

\begin{tabular}{|c|c|c|c|c|}
\hline \multirow{2}{*}{ Item } & \multirow{2}{*}{ Symbol } & \multirow{2}{*}{ Unit } & \multicolumn{2}{|c|}{ Experiment } \\
\hline & & & April 3 & July 23 \\
\hline $\begin{array}{l}\text { Calculated total volume of fresh sap. } \\
\text { Volume of film }\end{array}$ & $v^{1}-\ldots$ & $\begin{array}{l}\mathrm{dm}^{3} / \text { cell } \\
\mathrm{dm}^{3} / \text { cell }-.-\end{array}$ & $\begin{array}{r}1.0338 \\
.3847\end{array}$ & $\begin{array}{r}1.0136 \\
.3545\end{array}$ \\
\hline $\begin{array}{l}\text { Concentration of: } \\
\text { Fresh sap. }\end{array}$ & & $\mathrm{g} / \mathrm{dm}^{3}-\ldots$ & 133.80 & 156.01 \\
\hline Apparent sap.-.-..- & & $\mathrm{g} / \mathrm{dm}^{3}-\cdots-$ & 121.40 & 134. 84 \\
\hline Flood liquid.-.- & & $\mathrm{g} / \mathrm{dm}^{3} \ldots$ & 100.48 & 95.48 \\
\hline Surface area & & $\mathrm{m}^{2} / \mathrm{cell} . . . .$. & 2.170 & 2.128 \\
\hline Thickness of film & & $\mathrm{cm}$ & .0177 & .0167 \\
\hline Do & Mean $L_{2--}$ & & & \\
\hline Thickness of tissue........ & Mean $L_{1--}$ & $\mathrm{cm}$ & & \\
\hline 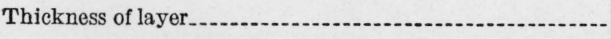 & Mean $L_{-.}$ & $\mathrm{cm}$ & & \\
\hline
\end{tabular}
$L_{2}$, where $L_{1}=t / 2$ and $t$ is the mean of $t_{1}$ and $t_{2}$.

TABLE 4.-Data for estimation of diffusion-layer thickness, equation 4

Other assumptions which appear equally tenable yield values of the same order. For example, it can be supposed that the volume of free sap on the fresh cossettes was such as would contain the quantity of polysaccharides which during the respective experimental extraction apparently was washed out of the cossette mass, rather than diffused out. Suppose also that the whole of the free fresh sap was replaced in the drained sample by a volume of flood liquid which, when mixed with the remaining fresh sap inside the particles, would yield apparent sap of the observed concentration $c^{\prime}$. In this case the indicated volume of the adhering flood liquid, divided by the area of the particles, yields the value $L_{2}=0.024 \mathrm{~cm}$ as the thickness of the film, instead of $L_{2}=0.017 \mathrm{~cm}$ as found above. 
Here it may be anticipated that the relations between the concentrations of the apparent sap and the apparent flood liquid, and also the relations between their apparent rates of change, indicate that the mean thicknesses of the films during the extractions were nearer $0.024 \mathrm{~cm}$. Thus the value of $0.017 \mathrm{~cm}$ is conservatively regarded as a minimum.

\section{RELIABILITY OF ESTIMATES}

Although, as a rule, the estimates of the same quantity by the three different observers, as presented in table 3 , seem to be in practical agreement, it should be emphasized that most of these estimates involve indirect methods and that frequently the resulting data are presented in a larger number of significant digits than the precision of the observations can justify. This fact, however, does not invalidate the estimates as they will be used in subsequent papers of this series.

Washington, August 8, 1936. 